\title{
Population Dynamics of Suez Pufferfish (Lagocephalus suezensis) in Iskenderun Bay
}

\author{
Meltem Manaşırı ${ }^{1,}$ * (D), Sinan Mavruk ${ }^{1}$, Hacer Yeldan ${ }^{1}$, Dursun Avşar $^{1}$
}

${ }^{1}$ Cukurova University Fisheries Faculty 01330 Balcali-Sarıcam, Adana/TURKEY.

\section{Article History}

Received October 16, 2019

Accepted August 28, 2020

First Online August 31, 2020

\section{Corresponding Author}

Tel.: +903223386084

E-mail: mozutok@cu.edu.tr

\section{Keywords}

Northeastern Mediterranean

Tetraodontidae

Length-weight Relationship

Growth

Mortality

\begin{abstract}
Suez pufferfish (Lagocephalus suezensis) is a Lessepsian species introduced to the Mediterranean via the Suez Canal. This study was carried out for the identification of some population dynamics parameters of Suez pufferfish (Lagocephalus suezensis) distributed along the western coast of Iskenderun Bay. Samples were seasonally collected from two transects at 10 and 20 m depth contours from 2006 to 2017 using a commercial bottom trawl net with $44 \mathrm{~mm}$ mesh size. A total of 1279 individuals were investigated. Among them 427 were males, 586 were females, 266 were juveniles. Total length ranged from 5.2 to $24.0 \mathrm{~cm}$ and mean length was $13.44 \pm 2.02$ ( \pm standard error) $\mathrm{cm}$; total weight ranged from 1.77 to $232.97 \mathrm{~g}$ and mean weight was $32.05 \pm$ $14.28 \mathrm{~g}$ for all individuals. Length-weight relationships were $\mathrm{W}=0.02 * \mathrm{TL}^{2.83}$ for males, $\mathrm{W}=0.02 * \mathrm{TL}^{2.82}$ for females, and $\mathrm{W}=0.02 * \mathrm{TL}^{2.89}$ for aggregated data. The von Bertalanffy growth parameters were as follows; $L_{\infty}=24.97 \mathrm{~cm}, \mathrm{~K}=0.60$ year ${ }^{-1}, \mathrm{t}_{0}=$ $0.28, R_{n}=0.145$ for all specimens. Growth performance index was calculated as 5.92 . Rates of total (Z) and natural (M) mortality was found to be 1.07 and 0.981 year $^{-1}$.
\end{abstract}

\section{Introduction}

The family, Tetraodontidae (pufferfishes) comprises 29 genera and 200 species generally distributed in marine waters (Froese \& Pauly, 2019). So far, seven species of tetraodontids have been reported in the Eastern Mediterranean two of which are native while the others are the Suez Canal intruders, referred to as Lessepsian species (Bilecenoglu et al., 2014).

The Suez pufferfish Lagocephalus suezensis Clark and Gohar (1953) is a lessepsian tetraodontid fish which was first recorded by Moumneimne (1977) on the Lebanese coast of the Mediterranean. Then its occurrence was reported from the Israeli coasts (Golani, 1996) and Turkish coasts (Bilecenoglu et.al., 2002) respectively. Studies on L. suezensis are mainly concerned with determination of its geographical distribution and bio-ecological characteristics (Golani, et al., 2006; Turan, 2007), length-weight relationship parameters (Ergüden et al., 2009; Ok, 2012; Başusta et al., 2013; Aydın et al., 2017; Bilge et al., 2017; Mutlu et al., 2017). The population parameters of $L$. suezensis were only investigated by Ok (2012) from Mersin Bay; however, there is no study in İskenderun Bay.

There are significant concerns in direct consumption of tetraodontids because they may contain a strong neurotoxin, namely tetrodotoxin in their various tissues (Kosker et al., 2016; Kosker et al., 2018; Kosker et al., 2019). For this reason, landing of pufferfishes is prohibited by Turkish and European fishery management authorities. This regulation is likely to reduce fishery pressure on pufferfishes and provide an advantage over native rivals in the eastern Mediterranean ecosystem. 
Iskenderun Bay is one of the most important fishing areas in the Northeastern Mediterranean (Gucu \& Bingel, 1994). The commercial fishing in Iskenderun Bay is primarily based on bottom trawling which is a multispecies fishery. Lessepsian fishes constitute an important part of this fishery as target, by-catch or discard species (Yemisken et al., 2014; Ozyurt et al., 2018).

The purpose of this study is to gather basic biological information on population status of Suez pufferfish, L. suezensis distributed in Iskenderun Bay, a semi enclosed shallow water body in the north-eastern tip of Mediterranean. In this context length-weight relationship, growth parameters, and total and natural mortality rates were calculated.

\section{Materials and Methods}

Samples were seasonally collected throughout 11 years, between 2006 and 2017 at two transects at 10 and $20 \mathrm{~m}$ depth contours between Yumurtalık and Botaş in the west coast of Iskenderun Bay, Northeastern Mediterranean (Figure 1). A commercial bottom trawler using a traditional Mediterranean type bottom trawl net with a $44 \mathrm{~mm}$ cod end mesh-size was employed for operations. Each tow lasted one hour. L. suezensis samples were sorted from the catch and carried to the laboratory at the Çukurova University Fisheries Faculty of in cold storage. In the laboratory, the length of specimens was measured to the nearest $0.1 \mathrm{~cm}$ and the weight was scaled to the nearest $0.01 \mathrm{~g}$. Then the sex of specimens was determined and recorded.

The medians and their 95\% confidence intervals were calculated for catch per unit effort (CPUE) values in weight and number (Mcgill et al., 1978). The significance of depth related and seasonal changes of CPUE values were tested using Wilcoxon rank sum tests and Kruskal-Wallis tests, respectively (Sokal \& Rohlf, 2012). Then significant variations were investigated by applying Chi square-based Nemenyi post-hoc tests (Pohlert, 2014). Interannual changes of CPUE values were tested using Mann-Kendal time series correlation (Hipel \& McLeod, 1994; McLeod, 2011). All statistical analyses were performed using $R$ language and environment for statistical computation (R Core Team, 2019).

Electronic length frequency analysis (ELEFAN) (Pauly et. al., 1984) was used to calculate vonBertalanffy growth functions (VBGF). The parameters of VBGF were estimated using ELEFAN function (Taylor \& Mildenberger, 2017) in TropFishR library (Mildenberger et al., 2017) of R. To find the best growth curve passing through the maximum number of peaks, different starting samples and starting lengths were subjected to the goodness-of-fit tests by assessing the ratio $\mathrm{Rn}=$ $\left(10^{\mathrm{ESP} / \mathrm{ASP}}\right) / 10$. The VBGF was as follows;

$$
L_{t}=L_{\infty}\left(1-e^{\left(-K\left(t-t_{0}\right)\right)}\right)
$$

$L_{t}$, is the total length at age $t, L_{\infty}$ is asymptotic length, $\mathrm{K}$ is growth coefficient and to was calculated using the empirical equation of Pauly (1980):

$$
\log _{10}\left(-t_{0}\right)=-0.3922-0.2752 \log _{10} L_{\infty}-1.038 \log _{10} K
$$

Pauly and Munro (1984)'s $\emptyset^{\prime}$ index was also calculated to compare the growth performance with previous studies;

$$
\emptyset^{\prime}=\ln K+2 \ln L_{\infty}
$$

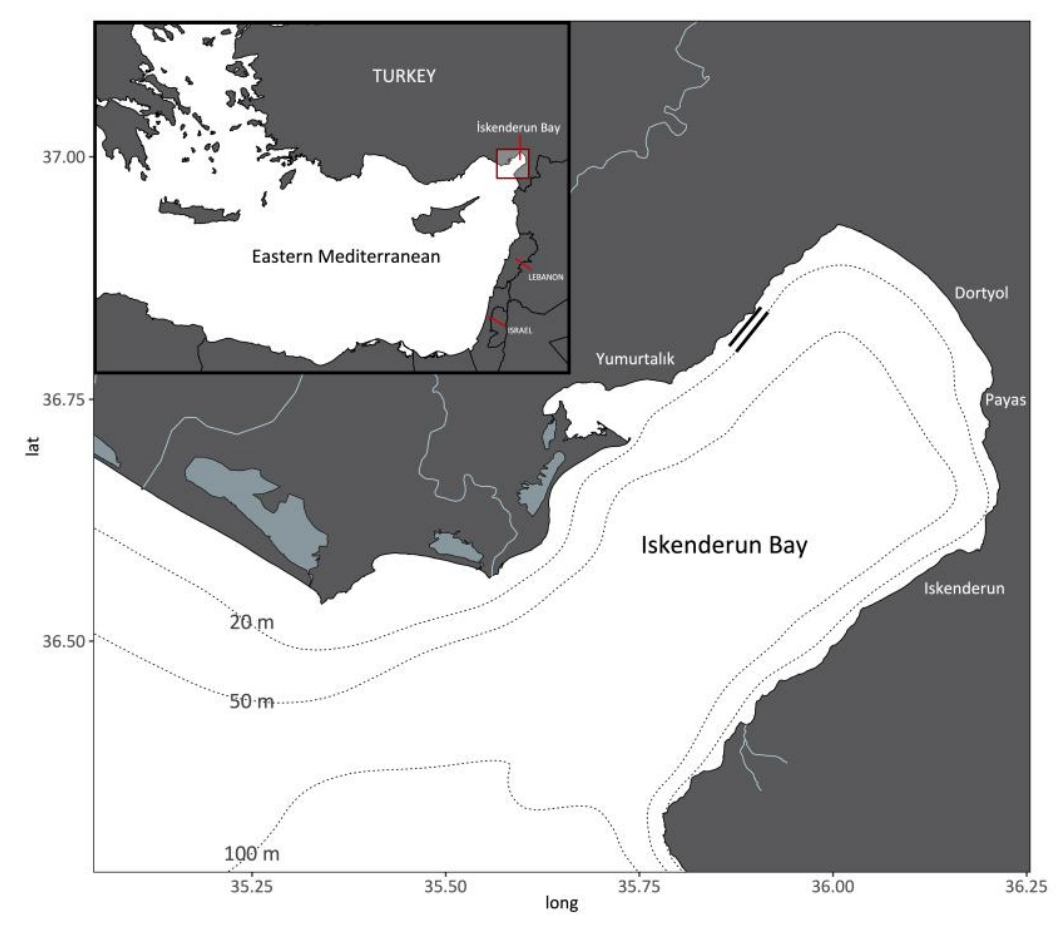

Figure 1. Sampling area and trawling transects at 10 and $20 \mathrm{~m}$. 
The length-weight relationships were determined according to the allometric equation given by Ricker (1975). The regressions were fitted using ordinary least square approximation after the length and weight were transformed to their natural logarithms. The allometric equation was as follows:

$$
W=a L^{b}
$$

Where; $\mathrm{W}$ is the total weight, $\mathrm{a}$ and $\mathrm{b}$ are regression coefficients, and $L$ is the total length. The confidence intervals ( $95 \%$ ) of the regression coefficients were calculated in order to compare sexes.

The difference of overall sex ratio from 1:1 was tested by using $\chi^{2}$ test. The interannual changes of sex ratio were investigated using Mann-Kendal time series correlation (Hipel \& McLeod, 1994; McLeod, 2011).

The rate of total mortality $(Z)$ was calculated using estimates of the growth parameters $\left(K, L_{\infty}\right)$, using the average length equation according to Beverton and Holt (1956):

$$
Z=K x \frac{L_{\infty}-\bar{L}}{\bar{L}-L^{\prime}}
$$

$\bar{L}$ : The average total length $(13.44 \mathrm{~cm})$ of fish used in the calculation of the growth coefficients and

$L^{\prime}$ : The lower limit of the smallest fully represented the total length class $(7 \mathrm{~cm})$ in the samples

The rate of natural mortality $(\mathrm{M})$ was calculated with the empirical formula given by (Then et.al., 2015) using the function M-empirical in TropFishR library (Mildenberger et al., 2017).

$$
M=0.418 K^{0.73} L_{\infty}^{-0.33}
$$

\section{Results}

During the study period $L$. suezensis was observed in 55 tows out of 92 bottom trawl operations (\%60). The median catch per unit effort (CPUE) was $183.98 \mathrm{~g} /$ hour
(5.49-362.47; 95\% confidence intervals) in weight, and 7 individual/hour $(1-13 ; 95 \% \mathrm{ci})$ in number. The depth related changes of CPUE was not significant neither in weight ( $W=1189, p=0.29$ ) nor in number $(W=1219$, $p$ value $=0.19)$; whereas, significant seasonal changes were detected both in weight $\left(\chi^{2}=32.33, \mathrm{df}=3, \mathrm{P}<0.001\right)$ and in number $\left(\chi^{2}=28.98, \mathrm{df}=3, \mathrm{P}<0.001\right)$. Based on Nemenyi post hoc test, the median of the weight and number values were lower in summer in contrast with other seasons $(P<0.05)$. The inter-annual changes of CPUE were not found to be significant both in weight (Mann-Kendal $\tau=-0.02, p=0.86$ ) and in number (MannKendal $\tau=-0.04, p=0.70$ ).

For population dynamics, a total of 1279 specimens were investigated. Among them $33.4 \%$ were male (427), $45.81 \%$ were female (586) and $20.79 \%$ were juveniles (266). The overall sex-ratio was calculated as $0.58(1: 0.73)$ and females were slightly dominant in the population $\left(\chi^{2}=24.34, \mathrm{P}<=0.001\right)$. Interannual changes in the sex ratio were not found to be significant (MannKendal $\tau=-0.21, p=0.54)$. The specimens smaller than 9 $\mathrm{cm}$ total length could not be sexed. Total length and weight of the examined fish ranged from $5.2-24.2 \mathrm{~cm}$ (Figure 2) to 77-232.97 g, respectively. Mean length and weight values and standard deviations were calculated as $13.44 \pm 2.02 \mathrm{~cm}$ and $32.05 \pm 14.28 \mathrm{~g}$, respectively. The seasonal length-frequency distributions and vonBertalanffy growth curves were shown in Figure 2.

The best fit to the length frequency distributions was obtained by the growth parameters as $L_{\infty}=24.97$ $\mathrm{cm}, \mathrm{K}=0.60$ year $^{-1}, \mathrm{Rn}=0.145$ for total individuals. Afterwards, to was calculated as -0.28 year. The growth performance index of the population was calculated as $\emptyset^{\prime}=5.92$. The total $(\mathrm{Z})$ and natural mortality (M) were calculated as 1.07 year $^{-1}, 0.98$ year $^{-1}$, respectively.

Length-weight relationship parameters of $L$. suezensis were given in Table 1 . In males, females and overall data, exponential coefficients (b) were significantly smaller than three, which indicates growth is negative allometric in $L$. suezensis population in Iskenderun Bay.

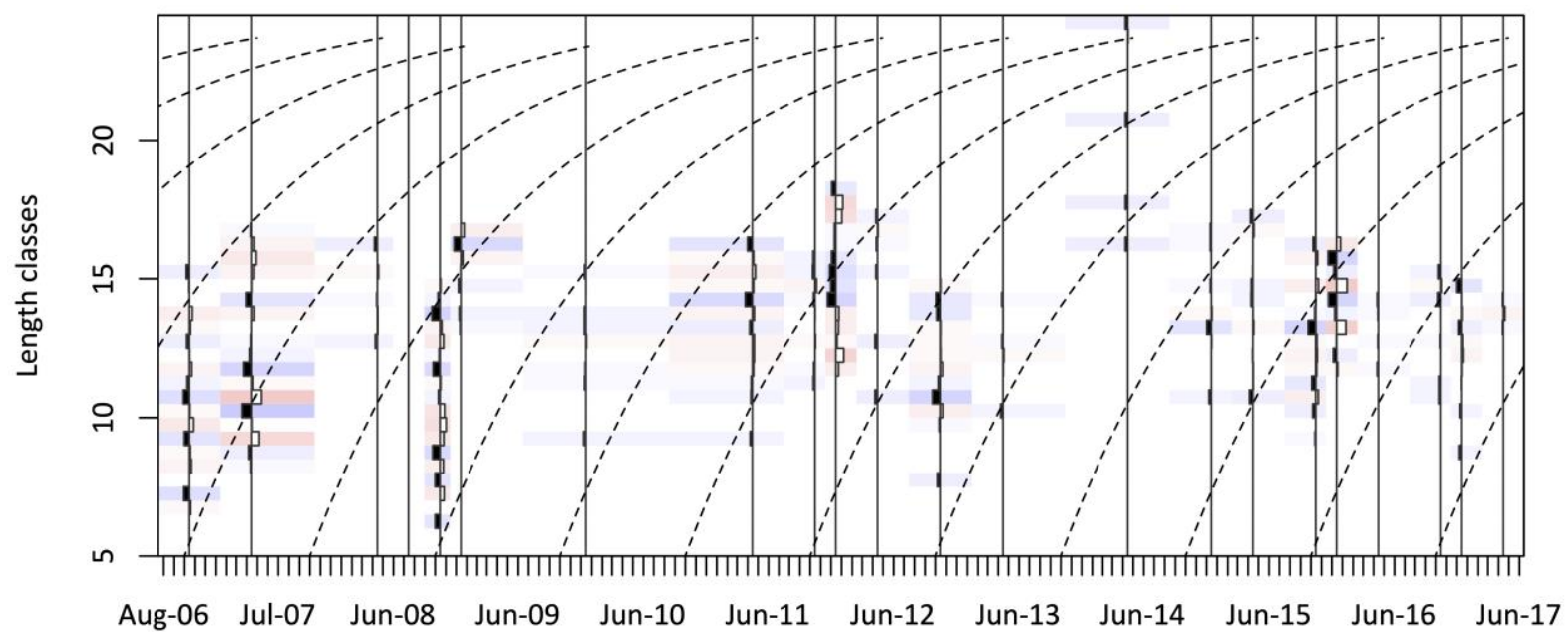

Figure 2. Length-Frequency distributions and von Bertalanffy growth curves. 
Table 1. Length-weight relationship parameters for males, females, juveniles and all specimens combined (the ranges in parentheses show $95 \%$ confidence intervals)

\begin{tabular}{|c|c|c|c|c|}
\hline \multirow[b]{2}{*}{ Sex } & \multirow[b]{2}{*}{ Individuals Numbers } & \multicolumn{3}{|c|}{ Length-Weight Relationship Parameters } \\
\hline & & $\mathrm{a}$ & b & $\mathrm{R}^{2}$ \\
\hline \multirow{3}{*}{ Male } & & 0.019 & 2.83 & \\
\hline & 427 & $(0.015-0.024)$ & $(2.74-2.92)$ & 0.91 \\
\hline & & 0.02 & 2.82 & \\
\hline \multirow[t]{2}{*}{ Female } & 586 & $(0.017-0.024)$ & $(2.76-2.88)$ & 0.93 \\
\hline & & 0.016 & 2.88 & \\
\hline \multirow[t]{2}{*}{ Juvenile } & 266 & $(0.007-0.039)$ & $(2.53-3.24)$ & 0.89 \\
\hline & & 0.017 & 2.89 & \\
\hline All Specimens & 1279 & $(0.015-0.018)$ & $(2.85-2.93)$ & 0.95 \\
\hline
\end{tabular}

\section{Discussion}

In general, length and weight ranges of $L$. suezensis individuals investigated in this study were in accordance with the previous studies performed in the Northeastern Mediterranean (Table 2). On the other hand, here we report a higher maximum length $(24 \mathrm{~cm})$ than those from the previous studies (Erguden et al., 2009; Ok, 2012; Basusta et al., 2013; Aydın et al., 2017; Bilge et al., 2017; Mutlu et al., 2017). Our samples were collected in an area where bottom trawl fishery is permanently restricted. Therefore, reduced fishery pressure may be a reason why larger fishes are present in the study area (Bingel, 1987; Cicek et al., 2014). Additionally, temporal coverage of our sampling is wider than previous studies and this should be considered while comparing the results.
In this study, the value of "b" was calculated as 2.83 for males, 2.82 for females and 2.89 for combined specimens including juveniles; there was no statistically significant difference between the two sexes (Table 1). Additionally, $L$. suezensis population inhabiting Iskenderun Bay showed negative allometry in growth characteristics. These results are in accordance with the previous studies performed in Iskenderun Bay (Erguden et al., 2009; Basusta et al., 2013). On the other hand, both isometry (Aydın et al., 2017) and positive allometry (Ok, 2012) were also reported for this species from Antalya and Mersin Bays, respectively. These controversies can be due to the differences among the spatiotemporal extent of the studies.

The von-Bertalanffy growth parameters of $L$. suezensis calculated in Iskenderun Bay (this study) and Mersin Bay (Ok, 2012) were compared in Table 3. The

Table 2. L. suezensis population parameters reported by different researchers in the Mediterranean

\begin{tabular}{|c|c|c|c|c|c|c|c|}
\hline Authors & $\begin{array}{l}\text { Erguden et } \\
\text { al., } 2009\end{array}$ & $\begin{array}{l}\text { Basusta et al., } \\
2013\end{array}$ & Ok, 2012 & $\begin{array}{l}\text { Bilge et al. } \\
2017\end{array}$ & $\begin{array}{l}\text { Aydın et al. } \\
2017\end{array}$ & $\begin{array}{l}\text { Mutlu et } \\
\text { al. } 2017\end{array}$ & This study \\
\hline Area & Iskenderun & Iskenderun & Erdemli- Tırtar & $\begin{array}{l}\text { South Aegean } \\
\text { Sea }\end{array}$ & Antalya Bay & $\begin{array}{l}\text { Antalya } \\
\text { Bay }\end{array}$ & Iskenderun \\
\hline $\mathrm{N}$ & 86 & 979 & 1430 & 84 & 150 & 747 & 1279 \\
\hline $\begin{array}{l}\text { Sex Ratio } \\
(\%)\end{array}$ & - & $\begin{array}{l}50.469 \\
49.54 \sigma^{\prime}\end{array}$ & $\begin{array}{l}32.39 \% \\
23.55 \sigma^{\circ}\end{array}$ & & & & $\begin{array}{l}33.40^{\prime \prime} \\
45.819\end{array}$ \\
\hline $\begin{array}{l}\mathrm{L}(\mathrm{cm}) \\
\text { Min-Max } \\
\text { Mean } \pm S h \\
\text { W (g) }\end{array}$ & $10.2-16.7$ & $\begin{array}{l}6.5-17.1 \\
13.944 \pm 1.296\end{array}$ & $6-23$ & $\begin{array}{l}8.6-15.9 \\
10.627\end{array}$ & $\begin{array}{l}11.5-26.8 \\
16.1 \pm 2.9\end{array}$ & $4-18.5$ & $\begin{array}{l}5.2-24.0 \\
13.44 \pm 2.02\end{array}$ \\
\hline $\begin{array}{l}\text { Min-Max } \\
\text { Mean } \pm S h\end{array}$ & $12.5-54.88$ & $\begin{array}{l}6.0-60.0 \\
31.63 \pm 8.903\end{array}$ & & $\begin{array}{l}7.9443 .56 \\
15.47\end{array}$ & $\begin{array}{l}18.7-87 \\
58.3 \pm 44.7\end{array}$ & $1.1-92.4$ & $\begin{array}{l}1.77-232.97 \\
32.05 \pm 14.28\end{array}$ \\
\hline$a$ & $0.02369+\sigma^{x}$ & $\begin{array}{l}0.01989+\sigma^{\prime \prime} \\
0.027 \sigma^{\prime \prime} \\
0.0145 \% \\
2.795 \%+\sigma^{\circ}\end{array}$ & $\begin{array}{l}0.0120 \%+\sigma^{\prime \prime} \\
0.0138 \sigma^{\prime \prime} \\
0.0115 \% \\
2.9981 \%+\sigma^{\pi}\end{array}$ & $0.0213 \%+\sigma^{\pi}$ & $0.01429+\sigma^{\circ}$ & $\begin{array}{l}0.01959+ \\
\sigma^{\prime \prime}\end{array}$ & $\begin{array}{l}0.0169+\sigma^{x} \\
0.019 \sigma^{\prime \prime} \\
0.02 \%+\sigma^{x} \\
2.89 \%+\sigma^{x}\end{array}$ \\
\hline b & $2.7499+\sigma^{\pi}$ & $\begin{array}{l}2.6764 \sigma^{\circ} \\
2.91449\end{array}$ & $\begin{array}{l}2.95060^{\prime \prime} \\
3.02529\end{array}$ & $2.75869+\sigma^{\circ}$ & $2.95579+0^{x}$ & $2.8369+\sigma^{\prime \prime}$ & $\begin{array}{l}2.832 \sigma^{\prime \prime} \\
2.8199\end{array}$ \\
\hline $\begin{array}{l}95 \% \mathrm{Cl} \text { of } \mathrm{b} \\
\text { S.E. (b) }\end{array}$ & \pm 0.063 & $\begin{array}{l} \pm 0.0014 \text { o }+\sigma^{x} \\
\pm 0.0025 \sigma^{x} \\
\pm 0.00199\end{array}$ & & $\begin{array}{l} \pm 0.0157 \\
\pm 0.0234\end{array}$ & +0.048 & & $\begin{array}{l} \pm 0.049+\sigma^{\prime \prime} \\
\pm 0.09 \sigma^{\prime \prime} \\
\pm 0.069\end{array}$ \\
\hline$r^{2}$ & 0.957 & 0.858 & 0.9957 & 0.871 & 0.9608 & & 0.95 \\
\hline
\end{tabular}


Table $\mathbf{3}$ Growth parameters of Lagocephalus suezensis

\begin{tabular}{|c|c|c|c|c|c|c|c|c|}
\hline \multirow[b]{2}{*}{ Sex } & \multicolumn{8}{|c|}{ von Bertalanffy Growth Parameters } \\
\hline & $\mathrm{L}_{\infty}(\mathrm{cm})$ & $\mathrm{K}\left(\right.$ year $\left.^{-1}\right)$ & $\mathrm{C}$ & WP & $t_{0}$ (year) & $\emptyset^{\prime}$ & Region & Authors \\
\hline Total & 24 & 0.90 & 0.90 & 0.10 & - & 6.25 & NW Levant & Ok, 2012 \\
\hline Total & 24.97 & 0.60 & - & - & -0.28 & 5.92 & Iskenderun Bay & This study \\
\hline
\end{tabular}

results were found to be close to each other (Table 3). The asymptotic length was higher and growth coefficient was lower in Iskenderun Bay, as well as the overall growth performance was found to be slightly lower in Iskenderun Bay, according to results of $\emptyset^{\prime}$ index.

\section{Conclusion}

Pufferfishes have no commercial importance due to the poison in their edible tissues. According to the recent studies, the amount of tetrodotoxin in the muscle tissue of $L$. suezensis is varying with season and constituting a potential health threat to consumers (Kosker et al., 2019). For this reason, landing of caught pufferfishes has been completely banned by the Turkish national fishery management authority (Anonymous, 2017). Pufferfishes are highly invasive species in the Mediterranean (Mavruk et al., 2017) and the absence of fishery pressure may contribute to their success in colonization and expansion in new habitats. Therefore, even though their direct consumption cannot be suggested, alternative usages of Suez pufferfishes should be explored in order to enhance its economic value and increase exploitation level so that the ecological advantage of low fishery pressure can be suppressed.

\section{Conflicts of Interest} interests.

The authors declare that they have no competing

\section{Acknowledgements}

We would like to express our graditutes to Çukurova University for their support.

\section{References}

Anonymous (2017). Republic of Turkey Ministry of Agriculture and Forestry General Directorate of Fisheries and Fisheries Communiqué No. 4/1 Regarding Commercial Fisheries Hunting (Notification No:2016/35). Madde 17/4.http://www.resmigazete.gov.tr/eskiler/2016/08/2 0160813-17.pdf. (Accessed 30 November 2017), in Turkish.

Aydin, M., Erkan, S., \& Dal, I. (2017). Length-weight relationships of the 3 Tetraodontidae (Lagocephalus sceleratus, Lagocephalus spadiceus, Lagocephalus suezensis) in the Antalya Bay. Turkish Journal of Maritime and Marine Sciences Volume: 3 Issue: 2 (2017) 67-74. http:// doi.org/10.1371/journal.pone.0011842
Basusta, A., Basusta, N., Ozer, E. I., Girgin, H., \& Aslan, E. (2013). Some Population Parameters of the Lessepsian Suez Puffer (Lagocephalus suezensiz) from Iskenderun Bay, Northeastern Mediterranean, Turkey. Pakistan Journal of Zoology, Vol 45(6): 1779-1782.

Bertalanffy, v. (1938). A quantitative theory of organic growth. Hum. Biol. 10: 181- 213.

Beverton, R.J.H., \& Holt, S.J. (1956). A review of methods for estimating mortality rates in fish populations, with special reference to sources of bias in catch sampling. Rapp. Cons. Int. Explor. Mer, 140: 67-83.

Bilecenoglu, M., Taskavak, E., \& Kunt, K. B. (2002). Range extention of three Lessepsian Migrant Fish (Fistularia commersoni, Sphyraena flavicaudata, Lagocephalus suenzensis) in the Mediterranean Sea. J. Mar. Biol. Assoc. U: K. 82: 525-526. http://doi.org/10.11646/zootaxa.113.1.1

Bilecenoglu, M., Kaya, M., Cihangir, B., \& Cicek, E. (2014). An updaded checklist of the marine fishes of Turkey. Turk J. Zool.38; 901-929. http://doi.org/10.3906/zoo-1405-60

Bilge, G., Filiz, H., \& Yapici, S. (2017). Length-Weight Relationships of Four Lessepsian Puffer Fish Species from Muğla Coasts of Turkey. Natural and Engineering Sciencens and International Journal Supplement, 2017, 2(3): 36-40. http://doi.org/10.28978/nesciences.369527

Bingel, F. (1987). Numerical Analysis of Coastal Fisheries in Eastern Mediterranean Final Report of Fisheries Project. Icel, 1987; Project number. 80070011, 312 (in Turkish).

Cicek, E., Karatas, M., Avsar, D., \& Moradi, M. (2014). Catch Composition of the bottom trawl fishery along the Coasts of Karataş-Adana (Northeastern Mediterranean Sea). International Journal of Aquatic Biology, 2 (5): 229237. http://doi.org/10.22034/ijab.v2i5.134

Erguden, D., Turan, C., \& Gurlek, M. (2009). Weight-Length Relationships for 20 Lessepsian Fish Species Caught By Bottom Trawl on the Coast of Iskenderun Bay (NE Mediterranean Sea, Turkey). Journal of Applied Ichthyology, 25: 133-135. http://doi.org/10.1111/j.1439-0426.2008.01198.x

Froese, R., \& Pauly, D. (2019). Fishbase. Retrieved from http://www.fish base.org.

Golani, D. (1996). The Marine Ichthyofauna of the Eastern Levant-History, Inventory, and Characterization. Israel Journal of Zoology. 42 (1): 15-50. http://doi.org/10.1080/00212210.1996.10688830

Golani, D., Ozturk, B., \& Basusta, N. (2006). The Fishes of the Eastern Mediterranean. Turkish Marine Research Foundation. No: 24, i̇stanbul-Türkiye. 260s.

Gucu, A. C., \& Bingel, F. (1994). Trawlable Species Assemblages on the Continental Shelf of the Northeastern Levant Sea (Mediterranean) with an Emphasis on Lessepsian Migration. Acta Adriatica, 35: 83-100.

Hipel, K. W., \& McLeod, Al. (1994). Time Series Modelling of Water Resources and Environmental Systems. Elsevier.

Kosker, A.R., Ozogul, F., Durmus, M., Ucar, Y., Ayas, D., Regenstein, J. M., \& Ozogul, Y. (2016). Tetrodotoxin levels in pufferfish (Lagocephalus sceleratus) caught in 
the Northeastern Mediterranean Sea. Food Chemistry.

210, 332-337.

http://doi.org/10.1016/j.foodchem.2016.04.122

Kosker, A. R., Ozogul, F., Durmus, M., Ucar, Y., Ayas, D., Simat, V., \& Ozogul, Y. (2018). First report on TTX levels of the yellow spotted pufferfish (Torquigener flavimaculosus) in the Mediterranean Sea. Toxicon 148, 101-106. http://doi.org/10.1016/j.toxicon.2018.04.018

Kosker, A. R., Ozogul, F., Ayas, D., Durmus, M., Ucar, Y., Regenstein, J. M., \& Ozogul, Y.E. (2019). Tetrodotoxin levels of three pufferfish species (Lagocephalus $s p$.) caught in the North-Eastern Mediterranean sea. Chemosphere 219, 95-99. http://doi.org/10.1016/j.chemosphere.2018.12.010

Mavruk, S., Bengil, F., Yeldan, H., Manasirli, M., \& Avsar, D. (2017). The trend of lessepsian fish populations with an emphasis on temperature variations in Iskenderun Bay, the Northeastern Mediterranean. Fisheries Oceanography, 26, 1-13. http://doi.org/ 10.1111/fog.12215

Mcgill, R., Tukey, J. W., \& Larsen, W. A. (1978). Variations of Box Plots. The American Statistician 32: 12-16.

McLeod, Al. (2011). Kendall: Kendall rank correlation and Mann-Kendall trend test.

Mildenberger, T. K., Taylor, M. H., \& Wolff, M. (2017). TropFishR: An R package for fisheries analysis with length-frequency data. Methods in Ecology and Evolution.

Moumneimne, N. (1977). Liste des poissons de la côte du Liban (Méditerranée orientale). Cybium, 1: 37-66.

Mutlu, E., Deval, M. C., \& Olguner, T. (2017). Length-Weight Relationships of Four Pufferfish Species in Antalya Bay. Natural and Engineering Sciencens and International Journal Volume 2, No 3, Supplement, 32.

Ok, M. (2012). Evaluation of the Demersal Fish Assemblages of the Northeastern Levant Sea. Phd Thesis. Institute of Marine Science, Department of Marıne Biology and Fisheries - METU, 227s.

Ozyurt, C. E., Perker, M., Kiyaga, V. B., Mavruk, S., \& Kayaalp, T. (2018). Biomass of some lessepsian fish species in the soft bottoms of Iskenderun Bay (Northeast Mediterranean). Review of Hydrobiology 11: 23-39.

Pauly, D. (1980). A selection of simple methods for the assessment of tropical fish stocks. FAO Fish. Circ. No 729: $54 \mathrm{p}$.

Pauly, D., Ingles, J., \& Neal, R. (1984). Application to shrimp stocks of objective methods for the estimation of vital statistics from length data. In: Penaeid shrimp-their biology and management: 220-234. (Fishing News Books, Farnham).

Pauly, D., \& Munro, J. L. (1984). Once more on the comparison of growth in fish and invertebrates. ICLARM Fish byte, 2 (1): $21 p$.

Pohlert, T., (2014). The Pairwise Multiple Comparison of Mean Ranks Package (PMCMR). R package: 27.

Ricker, W. E. (1975). Computation and interpretation of Biological statistics of fish populations. Bull. Fish. Res. Board. Can. (191): 382p.

Sokal, R. R., \& Rohlf, F. J. (2012). Biometry: the principles and practice of statistics in biological research. W. H. Freeman and Company: New York, NY.

Taylor, M. H., \& Mildenberger, T. K. (2017). Extending electronic length frequency analysis in R. Fisheries Management and Ecology.

R Core Team, (2019). R: A Language and Environment for Statistical Computing.

Then, A.Y., Hoenig, J. M., Hall, N. G., \& Hewitt, D. A. (2015). Evaluating the predictive performance of empirical estimators of natural mortality rate using information on over 200 fish species. ICES Journal of Marine Science.

Turan, C. (2007). Turkey Atlas of Marine Fishes Bony and Systematics. Nobel Bookstore, Adana. 549s.

Yemisken, E., Dalyan, C., \& Eryilmaz, L. (2014). Catch and discard fish species of trawl fisheries in the Iskenderun Bay (North-eastern Mediterranean) with emphasis on lessepsian and chondricthyan species. Mediterranean Marine Science 15: 380-389. http://doi.org/10.12681/mms.538. 